\title{
ANALISIS KOMPARATIF KINERJA PUSKESMAS PUTRI AYU DAN PUSKESMAS PAKUAN BARU DENGAN MENGGUNAKAN METODE BALANCED SCORECARD
}

\author{
Zulkifli $^{1)}$, Zamzami $^{2)}$, Yudi $^{3)}$ \\ ${ }^{1)}$ Alumni Magister Ilmu Akuntansi Pascasarjana Universitas Jambi Tahun 2019, \\ ${ }^{2 \& 3)}$ Dosen Pembimbing
}

\begin{abstract}
This study is a descriptive comparative study aimed to determine and compare the performance of health centers in putri ayu and pakuan baru using the balanced scorecard method. The health centers in putri ayu and pakuan baru chosen as the study site because the health centers in the two districts are already implementing a quality management system in accordance with Health Department standards and there is a health center that operates 24 hours in each. The study used primary data obtained from the answers given by the respondents and using secondary data from health centers financial data. he data analysis method used in this study was a paired sample ttest and Mann Whitney $U$ test which was testing two independent samples taken from both populations to find out the real differences between the average two populations whose distribution was the same. The results of this study showed measurements of Putri Ayu Health Center and Pakuan Baru Health Center using the balanced scorecard method viewed from four perspectives namely financial perspective, customer satisfaction perspective, internal and business process perspective and learning and growth perspective, apparently from the results of testing financial perspectives and business perspectives internal there is no significant difference, while the perspective of the learning and growth process, customer satisfaction processes there are differences.
\end{abstract}

Keywords: Balanced Scorecard, Performance, Puskesmas

\begin{abstract}
ABSTRAK
Penelitian ini bersifat deskriptif komparatif yaitu membandingkan kinerja Puskesmas Putri Ayu dan Puskesmas Pakuan Baru dengan menggunakan metode balanced scorecard. Puskesmas Putri Ayu dan Puskesmas Pakuan Baru dipilih sebagai lokasi penelitian karena dari 20 puskesmas yang ada di Kota Jambi, kedua puskesmas ini sudah menerapkan sistem manajemen mutu sesuai dengan standar Dinas Kesehatan dan memiliki pelayanan yang beroperasi 24 jam juga fasilitas rawat inap (perawatan) pada masing-masing kecamatan sehingga pelayanan lebih optimal dibandingkan dengan puskesmas lainnya. Penelitian ini menggunakan data primer berupa jawaban kuesioner yang diberikan responden dan data sekunder berupa data keuangan puskesmas. Metode analisis data yang digunakan dalam penelitian ini adalah uji paired sample t-test dan Mann Whitney $U$ yang merupakan pengujian dua sampel independen yang diambil dari kedua populasi untuk mengetahui perbedaan nyata antara rata-rata dua populasi yang distribusinya sama. Hasil penelitian ini menunjukan pengukuran kinerja Puskesmas Putri Ayu dan Puskesmas Pakuan Baru dengan menggunakan metode balanced scorecard dilihat dari empat perspektif yaitu perspektif keuangan, perspektif kepuasan pelanggan, perspektif proses bisnis dan internal dan perspektif pembelajaran dan pertumbuhan, ternyata dari hasil pengujian perspektif keuangan dan perspektif bisnis internal tidak terdapat perbedaan yang signifikan, sedangkan perspektif proses pembelajaran dan pertumbuhan, proses kepuasan pelanggan terdapat perbedaan.
\end{abstract}

Kata Kunci: Balanced Scorecard, Kinerja, Puskesmas 


\section{PENDAHULUAN}

\subsection{Latar Belakang}

Puskesmas sebagai salah satu jenis badan layanan umum (BLU) yang menyelenggarakan kesehatan kepada masyarakat, yang dibentuk untuk memberikan pelayanan kesehatan kepada masyarakat tanpa mengutamakan mencari keuntungan. Oleh karena itu ketersediaaan pelayananan kesehatan masyarakat yang merata bermutu dan berorientasi kepada kepuasan pasien merupakan tuntutan yang harus dipenuhi oleh puskesmas. Hal ini berarti bahwa puskesmas dituntut untuk memiliki kinerja yang baik. Untuk memenuhi tuntutan tersebut tentu saja puskesmas harus didukung oleh dana, sumber daya manusia yang bermutu dan profesional.

Penilaian kinerja puskesmas adalah suatu upaya untuk melakukan penilaian hasil prestasi kerja puskesmas. Laporan kinerja yang telah dibuat ini merupakan gambaran dari situasi dan kondisi yang ada, sehingga dari hasil yang ada dapat dinilai kinerja dari puskesmas itu sendiri. Puskesmas sebagai ujung tombak pelayanan kesehatan, tetapi hasilnya kontra produktif puskesmas semakin ditinggal oleh masyarakat dan tidak menjadi pilihan utama mereka mendapatkan kesehatan. Masih adanya anggapan dari masyarakat puskesmas kurang bermutu, pendapat masyarakat terhadap pelaksanaan sistem rujukan yang dianggap sebagian masyarakat merasa rumit apabila ingin mendapatkan pelayanan kesehatan yang murah karena pelayanan kesehatan di rumah sakit mengharuskan adanya rujukan dari puskesmas selain itu masih adanya keluhan masyarakat terhadap pelayanan puskesmas, yang dilakukan petugas puskesmas yang tidak peduli terhadap pasien, kedisiplinan pegawai puskesmas sampai masih adanya pungutan biaya yang tak seharusnya.

Berdasarkan penelitian M. Iqbal (2010) pengukuran kinerja Puskesmas Emperu Kabupaten Sintang dilihat dari segi jawaban responded termasuk kategori kurang baik untuk nilai pencapaian akhir kinerja keuangan mencapai $56,00 \%$, capaian akhir kinerja pelanggan mencapai $38,60 \%$ berarti termasuk kategori sangat tidak baik dan capaian akhir kinerja pertumbuhan dan pembelajaran mencapai $53,2 \%$ berarti termasuk kategori kurang baik. Sedangkan penelitian Yeni (2012) dilihat dari perspektif keuangan masih kurang efektif karena anggaran habis untuk belanja pegawai dan setiap tahun anggaran Puskesmas Pahandut menurun. Dan penelitian Siti (2014) dilihat dari perspektif keuangan dinilai dari penerimaan retribusi pada tahun 2014 tidak tercapai dan dari realisasi anggaran belanja puskesmas masih ada anggran yang belum terserap.

Pencitraan puskesmas yang cenderung belum mendapat perhatian serius dari penanggung jawabnya yang baru yaitu pemerintah kabupaten/kota. Sebagai tempat pelayanan kesehatan terdekat dengan pemukiman penduduk, masyarakat menganggap pelayanan di puskesmas kurang bermutu, stafnya kurang tanggap terhadap keluhan pasien, obatnya itu-itu saja dan menu pelayanan kurang dipahami oleh masyarakat setempat. Kondisi dan pencitraan puskesmas yang seperti ini semakin menjauhkan puskesmas dari masyarakat yang akan dilayani. Masyarakat akan lebih suka mencari pertolongan swasta.

Walaupun puskesmas merupakan Badan Layanan Umum yang non-profit oriented, tetapi harus tetap mengutamakan efektifitas dan efisiensi anggaran karena sebagian besar pengeluaran puskesmas masih didanai dari APBD. Jadi perlu diadakan suatu penilaian kinerja keuangan dan non keuangan agar pemerintah mengetahui efektifitas dan efisiensi penggunaan dana, perspektif konsumen, perkembangan karyawan dan perkembangan puskesmas.

Dari 20 puskesmas yang ada di Kota Jambi penulis memilih Puskesmas Putri Ayu dan Puskesmas Pakuan baru, dengan alasan karena puskesmas yang berada pada kedua kecamatan ini sudah menerapkan sistem manajemen mutu sesuai dengan standar Dinas Kesehatan dan memiliki pelayanan yang beropersai 24 jam juga fasilitas rawat inap (perawatan) pada masingmasing kecamatan sehingga pelayanan lebih optimal jika dibandingkan dengan puskesmas lainya (http://www.depkes.go.id)

Banlaced Scorecard dinilai cocok untuk organisasi nirlaba karena balanced scorecard tidak hanya menekankan pada aspek kuntitatif finansial, tetapi juga aspek kualitatif non finansial. Fenomena, penelitian - penelitian dan uraian diatas merupakan yang mendasari peneliti tertarik untuk melakukan penelitian tesis dengan judul "Analisis Komparatif Kinerja Puskesmas Putri Ayu dan Puskesmas Pakuan Baru dengan Menggunakan Metode Balanced Scorecard".

\subsection{Rumusan Masalah}

Perumusan masalah yang dapat diambil dari penelitian ini adalah sebagai berikut :

1. Apakah terdapat perbedaan kinerja antara Puskesmas Putri ayu dengan kinerja Puskesmas Pakuan Baru dinilai dari perspektif keuangan?

2. Apakah terdapat perbedaan antara kinerja Puskesmas Putri Ayu dengan kinerja Puskesmas Pakuan Baru dinilai dari perspektif pelanggan?

3. Apakah terdapat perbedaan kinerja antara Puskesmas Putri Ayu dengan kinerja Puskesmas Pakuan Baru dinilai dari persperktif proses bisnis?

4. Apakah terdapat perbedaan kinerja antara Puskesmas Putri Ayu dengan Puskesmas Pakuan Baru dinilai dari perspektif pembelajaran dan pertumuhan? 
5. Apakah terdapat perbedaan kinerja antara Puskesmas Putri Ayu dan Puskesmas Pakuan Baru dinilai dengan menggunakan metode balanced scorecard?

\subsection{Tujuan Penelitian}

Tujuan dalam penelitian ini adalah antara lain:

1. Untuk mengetahui apakah terdapat perbedaan antara kinerja Puskesmas Putri ayu dengan kinerja Puskesmas Pakuan Baru dinilai dari perspektif keuangan.

2. Untuk mengetahui apakah terdapat perbedaan antara kinerja Puskesmas Putri Ayu dengan kinerja Pakuan Baru dinilai dari perspektif pelanggan.

3. Untuk mengetahui apakah terdapat perbedaan antara kinerja Puskesmas Putri Ayu dengan kinerja Puskesmas Pakuan Baru dinilai dari persperktif proses bisnis.

4. Untuk mengetahui apakah terdapat perbedaan antara kinerja Puskesmas Putri Ayu dan kinerja Puskesmas Pakuan Baru dinilai dari persfektif pembelajaran dan pertumuhan.

5. Untuk mengetahui perbedaan antara Puskesmas Putri Ayu dengan Puskesmas Pakuan Baru dinilai dengan menggunakan metode balanced scorecard.

\section{TINJAUAN PUSTAKA, KERANGKA PEMIKIRAN DAN HIPOTESIS}

\subsection{Tinjauan Pustaka}

\subsubsection{Perspektif Keuangan}

Mulyadi (2007) indikator yang dapat digunakan untuk menilai kinerja perspektif keuangan yaitu: pertumbuhan pendapatan, pertumbuhan ROI, dan berkurangnya biaya. Menurut Munawir (1989), untuk analisa keuangan dapat dilakukan dengan analisis perbandingan dan analisis rasio. Analisis perbandingan menggunakan laporan keuangan dua periode atau lebih untuk diperbandingkan. Pembandingan bisa dilakukan secara vertikal atau horizontal. Sedangkan analisa rasio bertujuan mencari keterkaitan antara perkiraanperkiraan tertentu, baik dari setiap jenis laporan keuangan maupun antar jenis laporan keuangan. Macam angka-angka rasio yaitu (1) Rasio likuiditas Rasio-rasio yang paling sering digunakan untuk mencerminkan likuiditas, rasio ini mengidentifikasi kemungkinan masalah keuangan jangka pendek, (2) Rasio solvabilitas Rasio-rasio yang mengukur seberapa jauh rumah sakit dibiayai oleh pinjaman, (3) Rasio rentabilitas Rasiorasio yang mengukur keefektifan puskesmas dalam memanfaatkan harta atau sumber daya yang dimiliki, (4) Rasio kinerja Mengevaluasi penggunaan aset dari sudut pandang keuangan.

\subsubsection{Perspektif Kepuasan Pelanggan}

Tjiptono (2004), ukuran-ukuran pokok perspektif kepuasan pelanggan dalam balanced scorecard yaitu: Kepuasan pelanggan, memenuhi tingkat kepuasan pelanggan berdasarkan kinerja spesifik seperti kualitas, layanan, atau kehandalan pengiriman tepat waktu. Pengukuran kepuasan pelanggan menjadi hal yang penting untuk dilakukan oleh setiap organisasi. Kepuasan pelanggan menurut teori service quality dari Valerie Zaithamal dipengaruhi oleh lima dimensi yaitu (1) Tangibel Dimensi ini merupakan berbagai fasilitas yang dapat dilihat dan digunakan perusahaan dalam upaya memenuhi kepuasan pelanggan, seperti (a) Bangunan gedung/kantor, (b) Peralatan yang dimiliki perusahaan, (c) Penampilan karyawan/petugas perusahaan, (d) Usaha dalam mempromosikan perusahaan. (2) Reliability Merupakan kehandalan karyawan/petugas dalam melayani pelanggan sesuai yang dijanjikan, seperti (a) Kemampuan dalam menepati janji, (b) Kemampuan dalam memecahkan masalah pelanggan, (c) Kemampuan dalam memberikan pelayanan pertama yang baik, (d) Tidak melakukan kesalahan yang berarti. (3) Responsiveness Dimensi ini dimaksudkan sebagai sikap tanggap, mau mendengarkan, merespon pelanggan dalam usaha memuaskan pelanggan, seperti (a) Kemampuan perusahaan untuk memberikan informasi secara tepat, (b) Berusaha memberikan pelayanan dengan segera ketika diperlukan, (c) Berusaha memberikan pertolongan kepada pelanggan, (d)Tidak menunjukkan sikap sok sibuk. (4) Assurance yaitu Rasa aman/kenyamanan dirasakan atau diterima pelanggan, meliputi (a) Kredibilitas perusahaan, (b) Perusahaan menghargai bisnis pelanggan, (c) Memperlakukan pelanggan secara sopan santun, (d) Karyawan memiliki pengetahuan di bidangnya. (4) Emphaty poin-poin yang harus diperhatikan yaitu (a)Karyawan mampu memberikan perhatian yang bersifat pribadi kepada pelanggan, (b) Perusahaan mengerti kemampuan dan keinginan pelanggan, (c) Kenyamanan jam operasional perusahaan bagi pelanggan, (d) Mempelajari kebutuhan pelanggan sebelum mengambil tindakan apapun.

\subsubsection{Perspektif Proses Bisnis Internal}

Perspektif proses bisnis internal, perlu identifikasi berbagai proses internal penting yang harus dikuasai dengan baik oleh organisasi. Ukuran proses bisnis interna; berfokus pada berbagai proses internal yang akan berdampak besar kepada pelanggan dan pencapaian tujuan keuangan perusahaan. Pendekatan balanced scorecard pada umumnya akan mengidentifikasikan proses baru yang harus dikuasai dengan baik oleh perusahaan agar dapat memenuhi tujuan pelanggan dan finansial. Perspektif porses bisnis internal balanced scorecard terdiri atas tiga proses 
bisnis utama, yaitu (1) Proses inovasi merupakan salah satu kritikal proses, dimana efisiensi dan efektivitas serta ketepatan waktu dari proses inovasi ini akan mendorong terjadinya efisiensi biaya pada proses penciptaan nilai tambah bagi customer (Ciptani, 2002). Proses inovasi dilakukan dengan mengidentifikasi kebutuhan pelanggan saat ini dan yang akan datang serta mengembangkan solusi baru untuk kebutuhan pelanggan tersebut. (2) Proses operasional mengidentifikasi sumber-sumber pemborosan dalam proses operasional serta mengembangkan solusi masalah yang terdapat dalam proses operasional untuk meningkatkan efisiensi produksi, meningkatkan kualitas produk dan proses, serta memperpendek waktu siklus sehingga meningkatkan penyerahan produk yang berkualitas dan tepat waktu. (3) Proses pelayanan berkaitan dengan pelayanan kepada pelanggan, seperti pelayanan purna jual, penyelesaian masalah dari pelanggan dalam kesempatan pertama secara tepat, melakukan tindak lanjut secara proaktif dan tepat waktu, dan lain-lain.

\subsubsection{Proses Pembelajaran dan Pertumbuhan}

Aspek keempat yang menjadi unsur pengukuran kinerja organisasi dalam model balanced scorecard adalah proses pembelajaran dan pertumbuhan. Tujuantujuan dalam perspektif pembelajaran dan pertumbuhan merupakan pengedalian untuk mencapai keunggulan outcome dalam ketiga perspektif finansial, pelanggan dan proses bisnis internal (Gasperz, 2014). Sedangkan dalam Tjiptono (2004), tiga faktor kunci dalam pembelajaran dan pertumbuhan organisasi meliputi (1) kapabilitas karyawan dapat dibangun dengan melaksanakan pendidikan dan pelatihan bagi personel serta penerapan ilmu, pengetahuan, dan ketrampilan personel ini ke dalam pekerjaan mereka (Mulyadi, 2007). Hal senada juga diungkapkan dalam Mulyadi (2001) bahwa peluang untuk bertumbuh bagi karyawan dapat disediakan dalam bentuk pelatihan ketrampilan. Salah satu faktor kunci dalam pembangunan kepabilitas ini adalah kepuasan karyawan. (a) Reward (b) Promosi, (c) Turn over, (d) Hubungan dengan atasan dan rekan kerja, (e) Persepsi terhadap pekerjaan, (2) Kapabilitas sistem informasimerupakan infrastruktur teknologi mencakup infrastruktur fisik seperti mainframe dan jejaring komunikasi serta infrastruktur keahlian manajerial yang terdiri dari standar, perencanaan bencana, dan keamanan (Mulyadi, 2007). (3) Budaya organisasi Interaksi antara personel dan organisasi dari waktu ke waktu akan berdampak pada perkembangan kultur organisasi. Budaya organisasi adalah suatu tatanan aturan, interkoneksi yang biasanya tidak tertulis dan diikuti oleh setiap individu atau aktor dalam organisasi tersebut.

\subsection{Hipotesis}

Berdasarkan telaah teoritis, hasil-hasil penelitian terdahulu, maka dikembangkan hipotesis dengan penjelasan sebagai berikut :

H1: Terdapat perbedaan kinerja antara Puskesmas Putri Ayu dengan Puskesmas Pakuan Baru dinilai dari perspektif keuangan.

H2: $\quad$ Terdapat perbedaan kinerja antara Puskesmas Putri Ayu dengan Puskesmas Pakuan Baru dinilai dari perspektif pelanggan.

H3: Terdapat perbedaan kinerja antara Puskesmas Putri Ayu dengan Puskesmas Pakuan Baru dinilai dari perspektif proses bisnis.

H4: Terdapat perbedaan kinerja antara Puskesmas Putri Ayu dengan Puskesmas Pakuan Baru dinilai dari perspektif pembelajaran dan pertumbuhan

H5: Terdapt perbedaan kinerja Puskesmas Putri Ayu dengan Puskesmas Pakuan Baru dinilai dari metode balanced scorecard.

\section{METODE PENELITIAN}

\subsection{Objek dan Subjek Penelitian}

Pada penelitian ini objek penelitian berfokus pada Puskesmas Putri Ayu dan Puskesmas Pakuan Baru Kota Jambi.Sedangkan subjek penelitian adalah unit analisis atau unit observasi yang akan diteliti. Unit analisis dapat berupa: orang (manusia), organisasi, peristiwa, dan berbagai hal lainnya yang menjadi perhatian dalam kegiatan penelitian. Subjek dalam penelitian ini adalah karyawan, laporan keuangan, dan pasien di Puskesmas Putri Ayu dan Puskesmas Pakuan Baru kota Jambi.

\subsection{Metode Pengumpulan Data}

Pengumpulan data direncanakan akan dilakukan pada bulan Oktober 2018. Pengumpulan data dalam penelitian ini menggunakan beberapa cara, antara lain:

1) Data primer melalui wawancara mendalam dan penyebaran kuesioner kepuasan karyawan untuk mengetahui SOP, rujukan dan kelengkapan fasilitas serta mengetahui tingkat kepuasan karyawan dan melihat tingkat kepuasan pelanggan.

2) Data sekunder melalui penelusuran dokumendokumen Puskesmas Putri Ayu dan Puskesmas Pakuan Baru dari bagian keuangan, HRD, dan rekam medis yang terkait dengan penelitian.

3) Studi kepustakaan melalui literatur-literatur, hasil penelitian (Skripsi atau Tesis) dan buku-buku penunjang lainnya yang terkait dengan penelitian.

\subsection{Populasi dan Sampel Penelitian \\ 3.3.1. Populasi}

Populasi menunjukkan seluruh kelompok orang, kejadian atau sesuatu yang menjadi ketertarikan peneliti untuk diinvestigasi. Bisa juga dikatakan bahwa 
populasi merupakan total kumpulan elemen yang dari kumpulan tersebut akan dibuat kesimpulan (Nuryaman, 2015). Dalam penelitian ini populasinya adalah semua pelanggan \& karyawan Puskesmas Putri Ayu dan Puskesmas Pakuan Baru

1) Perspektif pelanggan

Data perspektif pelanggan diambil dari data sekunder yang diperoleh melalui penyebaran kuesioner oleh peneliti kepada pelanggan puskesmas yang berjumlah 80 orang pelanggan.

2) Perspektif pembelajaran dan pertumbuhan Data yang dikumpulkan dari penyebaran kuesioner dan wawancara secara langsung kepada karyawan puskesmas oleh peneliti yang berjumlah 20 orang karyawan.

\subsubsection{Sampel}

Sampling accidental adalah teknik penentuan sampel berdasarkan kebetulan, yaitu siapa saja yang secara kebetulan bertemu dengan peneliti dapat digunakan sebagai sampel. Teknik ini digunakan karena topik yang diteliti adalah mengenai citra yang dimana semua orang dapat memberikan penilaian terhadap citra (Sugiyono, 2012).

Jumlah anggota sampel sering dinyatakan dengan ukuran sampel. Jumlah sampel yang diharapkan $100 \%$ mewakili populasi adalah jumlah anggota populasi itu sendiri. Untuk penelitian jumlah populasi yang terlalu banyak akan di ambil untuk dijadikan sampel dengan harapan jumlah sampel yang di ambil dapat mewakili populasi yang ada. Untuk menentukan ukuran sampel yang dibutuhkan dalam penelitian ini digunakan rumus Slovin. Pemakaian rumus ini mempunyai asumsi bahwa populasi berdistribusi normal, dengan menggunakan margin error atau kasalahan $10 \%$

$$
\mathrm{n}=\frac{\mathrm{N}}{1+\left(\mathrm{N} \times e^{2}\right)}
$$

Keterangan:

$\mathrm{n}=$ Ukuran sampel

$\mathrm{N}=$ Populasi

$e=$ Tingkat kesalahan $10 \%$

Tabel 1.

Jumlah Pasien dan Karyawan Puskesmas Putri Ayu Tahun 2015 - 2017

\begin{tabular}{|c|c|c|}
\hline No. & Keterangan & $\begin{array}{c}\text { Jumlah Pasien \& } \\
\text { Karyawan }\end{array}$ \\
\hline 1 & Pasien 2015-2017 & 189.864 \\
\hline 2 & Karyawan Puskesmas & 83 \\
\hline \multicolumn{2}{|c|}{ Total } & $\mathbf{1 8 9 . 9 4 7}$ \\
\hline
\end{tabular}

Sumber: Rekam Medis 2018 \& Data Kepegawaian (Puskesmas Putri Ayu).

$$
\begin{aligned}
\mathrm{n} & =\frac{\mathrm{N}}{1+\left(\mathrm{N} \mathrm{x} e^{2}\right)} \\
& =\frac{189.947}{1+\left(189.947 \times 0,1^{2}\right)} \\
& =\frac{189.947}{1.900,47} \\
& =99,94 \text { digenapkan menjadi } 100 \\
\mathrm{n} & =100
\end{aligned}
$$

dikarenakan pada penelitian ada 2 kelompok maka ditentukan $80 \%$ untuk sampel pasien dan $20 \%$ untuk sampel karyawan jadi totalnya adalah 80 orang pasien dan 20 karyawan puskesmas.

Tabel 2.

Jumlah Pasien dan Karyawan Puskesmas Pakuan Baru tahun 2015 - 2017

\begin{tabular}{|c|l|c|}
\hline NO & Keterangan & $\begin{array}{c}\text { Jumlah Pasien } \\
\text { \& Karyawan }\end{array}$ \\
\hline 1 & Pasien 2015-2017 & 148.968 \\
\hline 2 & Karyawan Puskesmas & 65 \\
\hline \multicolumn{2}{|c|}{ Total } & $\mathbf{1 4 9 . 0 3 3}$ \\
\hline
\end{tabular}

Sumber: Rekam Medis 2018 \& Data Kepegawaian (Puskesmas Pakuan Baru).

$$
\begin{aligned}
\mathrm{n} & =\frac{\mathrm{N}}{1+\left(\mathrm{N} \mathrm{x} e^{2}\right)} \\
& =\frac{149,033}{1+\left(149.033 \times 0,1^{2}\right)} \\
& =\frac{149.033}{1.491,033} \\
& =99,93 \text { digenapkan menjadi } 100 \\
\mathrm{n} & =100
\end{aligned}
$$

dikarenakan pada penelitian ada 2 kelompok maka ditentukan $80 \%$ untuk sampel pasien dan $20 \%$ untuk sampel karyawan jadi totalnya adalah 80 orang pasien dan 20 karyawan rumah puskesmas

\subsection{Teknik Analisis Data}

3.4.1. Analisis Deskiptif

Metode analisis yang digunakan dalam penelitian ini adalah dengan pendekatan deskriptif kuantitatif. Metode ini dilakukan dengan cara:

a. Memaparkan dan menjelaskan data-data yang telah didapatkan, seperti data keuangan puskesmas, data pasien, laporan kinerja standar pelayanan puskesmas dan data karyawan.

b. Memberikan skor masing-masing indikator kinerja yang terdapat dalam keempat perspektif 
balanced Scorecard sesuai dengan standar yang sudah ditetapkan tiap-tiap perspektif.

\begin{tabular}{|c|c|}
\hline Skor & Kriteria \\
\hline 3 & Baik \\
\hline 2 & Cukup \\
\hline 1 & Jelek \\
\hline
\end{tabular}

c. Melakukan penilaian kinerja yang dicapai oleh puskesmas dari hasil pemberian skor pada masingmasing indikator dari empat perspektif Balanced Scorecard menggunakan perhitungan yang ditetapkan oleh Valva dalam Septianie (2013), sebagai berikut:

Kinerja $=\frac{\text { Total Score }}{\text { Score Maksimal }} \times 100 \%$

a). Sangat baik: $80 \%-100 \%$

b). Baik: $60 \%-<80 \%$

c). Cukup baik: $40 \%-<60 \%$

d). Tidak baik: $20 \%-<40 \%$

e). Sangat tidak baik: $0 \%-<20 \%$

\subsubsection{Uji Paired Sample t-test dan Uji Mann Whitney $U$}

Teknis analisis data dalam penelitian kuantitatif menggunakan statistik. Terdapat dua macam statistik yang digunakan untuk analisis data dalam penelitian, yaitu statistik deskriptif dan statistik inferensial. Statistik inferensial meliputi statistik parametris dan statistik nonparametris (Sugiyono, 2007). Metode analisis yang digunakan dalam penelitian ini untuk menguji hipotesis statistik parametris pada program Statistikal Product and Service Solution (SPSS) versi 23 dengan menggunakan paired samples $t$ test.

Uji hipotesis dengan metode paired sample t test digunakan untuk mengetahui perbandingan dua rata rata sampel yang berpasangan. Uji ini dilakukan pada subyek yang diuji untuk situasi sebelum dan sesudah proses atau mendapat perlakuan sehingga tepat untuk menguji efektivitas penerapan job sheet yang dikembangkan sebagai pedoman praktik. Uji hipotesis metode two related samples test atau uji wilcoxon digunakan sebagai alternatif dari uji paired samples $t$ test jika data tidak berdistribusi normal. Metode two independent samples test atau uji Mann Whitney sebagai alternatif dari uji independent samples t test jika data tidak berdistribusi normal.

Mann Whitney $U$ test digunakan untuk dua sampel bebas jika data setidaknya ordinal, uji ini merupakan uji $t$ alternatif tanpa asumsi data setidaknya ordinal. Dalam menghitung uji $U$, kombinasi semua observasasi dan buatlah ranking, secara aljabar dari yang terkecil hingga yang besar. Skor negatif terbesar mendapatkan ranking paling rendah. Jika terdapat ranking yang sama, tetapkan rata-rata seperti uji lainnya. Dengan uji ini juga dapat menguji sampelsampel yang tidak sama. Setelah melakukan ranking, nilai-nilai ranking untuk masing-masing sampel dijumlahkan. Tujuan adalah untuk mengetahui apakah ada perbedaan parameter dari dua kelompok sampel yang dependen (Cooper, 2006)

$$
\begin{array}{ll}
\text { Rumus: } & U=\mathrm{n}_{1} \mathrm{n}_{2}+\frac{n_{1}\left(n_{1}+1\right)}{2}-\mathrm{R}_{1} \\
\text { Keterangan: } & U=\mathrm{n}_{1} \mathrm{n}_{2}+\frac{n_{1}\left(n_{1}+1\right)}{2}-\mathrm{R}_{2} \\
& \mathrm{n}_{1}=\text { jumlah sampel 1 } \\
& \mathrm{n}_{2}=\text { jumlah sampel 2 } \\
& \mathrm{R}_{1}=\text { jumlah rangking pada sampel 1 } \\
& \mathrm{R}_{2}=\text { jumlah rangking pada samel 2 }
\end{array}
$$

Dengan persamaan ini akan memperoleh dua nilai $U$, yang pertama menggunakan $R_{1}$, dan yang kedua menggunakan $R_{2}$. Untuk tujuan pengujian, digunakan nilai $U$ yang lebih kecil.

\section{HASIL DAN PEMBAHASAN}

Berikut adalah hasil penelitian yang telah dilakuakan di Puskesmas Putri Ayu dan Puskesmas Pakuan Baru dilihat dari perspektif keuangan dengan mengukur tingakat pendapatan, tingakat pengeluaran dan Perbandingan pendapatan dan pengeluaran.

Tabel 3.

Tingkat Pendapatan Puskesmas Putri Ayu Tahun 2015-2017

\begin{tabular}{|c|c|c|r|}
\hline Thn & $\begin{array}{c}\text { Total } \\
\text { Pendapatan }\end{array}$ & $\begin{array}{c}\text { Selisih } \\
\text { Pendapatan }\end{array}$ & $\begin{array}{c}\text { Tingkat } \\
\text { Pendapatan }\end{array}$ \\
\hline 2015 & Rp. $1.984 .394 .350,00$ & & \\
\hline 2016 & Rp. $2.829 .771 .100,00$ & Rp. $845.376 .750,00$ & $42,60 \%$ \\
\hline 2017 & Rp. $3.334 .723 .600,00$ & Rp. 504.952.500,00 & $17,84 \%$ \\
\hline $\begin{array}{c}\text { Rata } \\
\text {-rata }\end{array}$ & Rp. 2.716.296.350,00 & Rp. 450.109.750,00 & $\mathbf{4 8 , 5 4 \%}$ \\
\hline
\end{tabular}

Sumber: Data keterangan dari bagian keuangan Puskesmas Putri Ayu

Tabel 4.

Tingkat Pendapatan Puskesmas Pakuan Baru Tahun 2015-2017

\begin{tabular}{|c|c|c|r|}
\hline Thn & $\begin{array}{c}\text { Total } \\
\text { Pendapatan }\end{array}$ & $\begin{array}{c}\text { Selisih } \\
\text { Pendapatan }\end{array}$ & $\begin{array}{c}\text { Tingkat } \\
\text { Pendapatan }\end{array}$ \\
\hline 2015 & Rp. $1.823 .847 .000,00$ & & - \\
\hline 2016 & Rp. $1.773 .575 .600,00$ & (Rp. $50.271 .400,00)$ & $-2,75 \%$ \\
\hline 2017 & Rp. $2.232 .256 .587,00$ & Rp. $458.680 .987,00$ & $25,86 \%$ \\
\hline $\begin{array}{l}\text { Rata- } \\
\text { rata }\end{array}$ & Rp. 1.943.226.395,07 & Rp. 136.136.529,00 & $\mathbf{7 , 7 0 \%}$ \\
\hline
\end{tabular}

Sumber: Data keterangan dari bagian keuangan Puskesmas Pakuan Baru

Dapat Disimpulkan bahwa dilihat dari tingkat pendapatan Puskesmas Putri Ayu jauh lebih baik dari tingkat Pendapatan Puskesmas Pakuan Baru dengan selisis sebesar 40.84\%. Pendapatan Puskesmas Putri 
Ayu dari tahun 2015 sampai dengan tahun 2017 selalu mengalami peningkatan pendapatan sedangkan pendapatan Puskesmas Pakuan Baru pada tahun 2016 mengalami penurunan pendapatan sebesar $2.75 \%$.

Tabel 5.

Tingkat Pengeluaran Puskesmas Putri Ayu

Tahun 2015-2017

\begin{tabular}{|c|c|c|c|}
\hline Thn & $\begin{array}{c}\text { Total } \\
\text { Pendapatan } \\
\end{array}$ & $\begin{array}{c}\text { Selisih } \\
\text { Pendapatan } \\
\end{array}$ & $\begin{array}{c}\text { Tingkat } \\
\text { Pendapatan } \\
\end{array}$ \\
\hline 2015 & Rp. 1.845.643.850,00 & - & - \\
\hline 2016 & Rp. 2.178.636.689,00 & Rp. 332.992.839,00 & $17,5 \%$ \\
\hline 2017 & Rp. 2.671.603.221,00 & Rp. $492.966 .532,00$ & $22,62 \%$ \\
\hline $\begin{array}{l}\text { Rata- } \\
\text { rata }\end{array}$ & Rp. 2.231.961.253,03 & Rp. 275.319.790,33 & $13,37 \%$ \\
\hline
\end{tabular}

Tabel 6.

Tingkat Pengeluaran Puskesmas Pakuan Baru

Tahun 2015-2017

\begin{tabular}{|c|c|r|r|}
\hline Thn & $\begin{array}{c}\text { Total } \\
\text { Pendapatan }\end{array}$ & \multicolumn{1}{|c|}{$\begin{array}{c}\text { Selisih } \\
\text { Pendapatan }\end{array}$} & $\begin{array}{c}\text { Tingkat } \\
\text { Pendapatan }\end{array}$ \\
\hline 2015 & Rp. $1.554 .959 .709,00$ & - & - \\
\hline 2016 & Rp. $1.384 .992 .550,00$ & $\begin{array}{r}(\mathrm{Rp} . \\
169.967 .159,00)\end{array}$ & $-10,93 \%$ \\
\hline 2017 & Rp. $2.157 .799 .713,00$ & Rp. 772.807.163,00 & $55,8 \%$ \\
\hline $\begin{array}{l}\text { Rata- } \\
\text { rata }\end{array}$ & Rp. 1.699.250.657,03 & Rp. 200.946.668,00 & $\mathbf{1 4 , 9 5 \%}$ \\
\hline
\end{tabular}

Sumber:Data keterangan dari bagian keuangan Puskesmas Pakuan Baru

Dapat disimpulkan dilihat dari tingkat pengeluaran puskesmas dari tahun 2015 sampai dengan tahun 2017 ternyata tingkat pengeluaran Puskesmas Putri ayu lebih kecil dibandingakan dengan tingkat pengeluaran Puskesmas Pakuan Baru dengan Selisi $1,57 \%$ tetapi dari tingkat pengeluaran tersebut kedua puskesmas tersebut masih dalam kategori baik.

Tabel 7.

Perbandingan Pendapatan dan Pengeluaran

Puskesmas Putri Ayu Tahun 2015-2017

\begin{tabular}{|c|c|c|r|}
\hline Thn & $\begin{array}{c}\text { Total } \\
\text { Pendapatan }\end{array}$ & $\begin{array}{c}\text { Selisih } \\
\text { Pendapatan }\end{array}$ & $\begin{array}{c}\text { Tingkat } \\
\text { Pendapatan }\end{array}$ \\
\hline 2015 & Rp. $1.984 .394 .350,00$ & Rp. $1.845 .643 .850,00$ & $107,5 \%$ \\
\hline 2016 & Rp. $2.829 .771 .100,00$ & Rp. $2.178 .636 .689,00$ & $129,88 \%$ \\
\hline 2017 & Rp. $3.334 .723 .600,00$ & Rp. $2.671 .603 .221,00$ & $124,82 \%$ \\
\hline $\begin{array}{l}\text { Rata- } \\
\text { rata }\end{array}$ & Rp. 2.716.296.350,00 & Rp. 2.231961253,03 & $\mathbf{1 2 0 , 7 3 \%}$ \\
\hline
\end{tabular}

Sumber:Data keterangan dari bagian keuangan Puskesmas Putri Ayu
Tabel 8.

Perbandingan Pendapatan dan Pengeluaran Puskesmas Pakuan Baru Tahun 2015-2017

\begin{tabular}{|l|c|c|r|}
\hline Thn & $\begin{array}{c}\text { Total } \\
\text { Pendapatan }\end{array}$ & $\begin{array}{c}\text { Selisih } \\
\text { Pendapatan }\end{array}$ & $\begin{array}{c}\text { Tingkat } \\
\text { Pendapatan }\end{array}$ \\
\hline 2015 & Rp. $1.823 .847 .000,00$ & Rp. $1.554 .959 .709,00$ & $117,29 \%$ \\
\hline 2016 & Rp. $1.773 .575 .600,00$ & Rp. $1.384 .992 .550,00$ & $128,05 \%$ \\
\hline 2017 & Rp. $2.232 .256 .587,00$ & Rp. $2.157 .799 .713,00$ & $103,45 \%$ \\
\hline $\begin{array}{l}\text { Rata- } \\
\text { rata }\end{array}$ & Rp. 1.943.226.395,07 & Rp.1.699.250.657,03 & $\mathbf{1 1 6 , 2 6 \%}$ \\
Sumber: Data keterangan dari bagian & keuangan \\
Puskesmas Pakuan Baru
\end{tabular}

Dapat disimpulkan dilihat dari perbandingan pendapatan dengan pengeluaran Puskesmas dari tahun 2015 sampai dengan 2017, ternyata puskesmas Putri ayu lebih besar di bandingkan dengan Puskesmas Pakuan Baru dengan selisih sebesar 4,47\%.

Penilaian terhadap perspektif pelanggan erat kaitannya tentang pelayanan dokter, karyawan, serta layanan dan fasilitas yang tersedia dirumah sakit menggunakan data sekunder yang diperoleh dari survey terhadap kepuasan pelanggan yang dilakukan oleh peneliti sendiri. Jumlah responden pada penelitian ini berjumlah 80 responden yang merupakan pasien Puskesmas Putri Ayu dan 80 responden yang merupakan pasien Puskesmas Pakuan Baru. Untuk memperhitungkan pertumbuhan kunjungan pelanggan digunakan data jumlah kunjungan pasien Puskesmas Putri Ayu dan Puskesmas Pakuan Baru yang di peroleh dari bagian Rekam Medik (Medical Record).

Tabel 9.

Tingkat Kepuasan Pelanggan terhadap Pelayanan Karyawan Puskesmas Putri Ayu

\begin{tabular}{|c|c|c|c|c|}
\hline \multirow{2}{*}{ Pertanyaan } & \multicolumn{3}{|c|}{ Tanggapan Responden } & \multirow{2}{*}{$\begin{array}{c}\% \\
\text { Skor } \\
\text { Aktual }\end{array}$} \\
\hline & Aktual & Ideal & $\mathbf{A} / \mathbf{I}$ & \\
\hline $\begin{array}{l}\text { Respon petugas } \\
\text { pendaftaran }\end{array}$ & 291 & 346 & 0,84 & 84,10 \\
\hline Respon perawat & 292 & 351 & 0,83 & 83.19 \\
\hline Respon dokter & 315 & 352 & 0,89 & 89,48 \\
\hline Respon petugas kasir & 304 & 341 & 0,89 & 89,14 \\
\hline Respon petugas farmasi & 277 & 346 & 0,80 & 80,05 \\
\hline $\begin{array}{l}\text { Sikap petugas } \\
\text { pendaftaran }\end{array}$ & 288 & 351 & 0.82 & 82,05 \\
\hline Sikap perawat & 288 & 350 & 0,82 & 82,28 \\
\hline Sikap dokter jaga & 311 & 353 & 0,88 & 88,10 \\
\hline Sikap petugas kasir & 300 & 348 & 0,86 & 86,20 \\
\hline Sikap petugas farmasi & 276 & 348 & 0,79 & 79.31 \\
\hline Rata-rata & 294,2 & 348,6 & 0.84 & 84.39 \\
\hline
\end{tabular}

Sumber: Rekapitulasi Kuesioner Penelitian Puskesmas Putri ayu 
Tabel 10.

Tingkat Kepuasan Pelanggan terhadap Pelayanan Karyawan Puskesmas Pakuan Baru

\begin{tabular}{|c|c|c|c|c|}
\hline \multirow[t]{2}{*}{ Pertanyaan } & \multicolumn{3}{|c|}{$\begin{array}{l}\text { Tanggapan } \\
\text { Responden }\end{array}$} & \multirow{2}{*}{$\begin{array}{c}\% \\
\text { Skor } \\
\text { Aktual }\end{array}$} \\
\hline & Aktual & Ideal & $\mathbf{A} / \mathbf{I}$ & \\
\hline $\begin{array}{l}\text { Respon petugas } \\
\text { pendaftaran }\end{array}$ & 339 & 346 & 0,97 & 97,97 \\
\hline Respon perawat & 301 & 351 & 0,85 & 85,75 \\
\hline Respon dokter & 323 & 352 & 0,91 & 91,76 \\
\hline Respon petugas kasir & 303 & 341 & 0,88 & 88,85 \\
\hline Respon petugas farmasi & 290 & 346 & 0,83 & 83,81 \\
\hline $\begin{array}{l}\text { Sikap petugas } \\
\text { pendaftaran }\end{array}$ & 338 & 356 & 0.94 & 94,44 \\
\hline Sikap perawat & 305 & 355 & 0,85 & 85,91 \\
\hline Sikap dokter jaga & 320 & 356 & 0,89 & 89,88 \\
\hline Sikap petugas kasir & 312 & 357 & 0,87 & 87,39 \\
\hline Sikap petugas farmasi & 288 & 356 & 0,80 & 80,89 \\
\hline Rata-rata & 303,8 & 349,2 & 0.87 & 88.66 \\
\hline
\end{tabular}

Sumber: Rekapitulasi Kuesioner Penelitian Puskesmas Pakuan Baru

Dapat di simpulkan bahwa tingkat kepuasan Pasien terhadap pelayanan karyawan antara Puskesmas Putri ayu dengan Puskesmas Pakuan baru sama-sama masuk kedalam ketegori sangat baik walaupun secara persentase Puskesmas Pakuan Baru lebih tinggi yaitu sebesar 88,66\% sedangankan Puskesmas Putri Ayu sebesar $84,39 \%$.

Tabel 11.

Tingkat Kepuasan Pasien Terhadap Pelayanan Puskesmas Puskesmas Putri Ayu

\begin{tabular}{|l|c|c|c|c|}
\hline \multirow{2}{*}{ Pertanyaan } & \multicolumn{3}{|c|}{ Tanggapan Responden } & \%Skor \\
\cline { 2 - 4 } & Aktual & Ideal & A/I & \\
\hline $\begin{array}{l}\text { Prosedur pendaftaran } \\
\text { pasien }\end{array}$ & 296 & 322 & 0.89 & 89.15 \\
\hline $\begin{array}{l}\text { Prosedur } \\
\text { pemerikasaan \& } \\
\text { pengobatan }\end{array}$ & 280 & 329 & 0.85 & 85.10 \\
\hline Prosedur Pembayaran & 290 & 328 & 0.88 & 88.41 \\
\hline $\begin{array}{l}\text { Prosedur } \\
\text { pengambilan obat }\end{array}$ & 285 & 332 & 0.85 & 85.84 \\
\hline $\begin{array}{l}\text { Kejelasan waktu } \\
\text { tunggu pemeriksaan }\end{array}$ & 290 & 350 & 0.82 & 82.85 \\
\hline $\begin{array}{l}\text { Kejelasan informasi } \\
\text { penyakit }\end{array}$ & 308 & 354 & 0.87 & 87 \\
\hline $\begin{array}{l}\text { Kejelasan waktu } \\
\text { tunggu pengambilan } \\
\text { obat }\end{array}$ & 276 & 348 & 0.79 & 79.31 \\
\hline $\begin{array}{l}\text { Kejelasan } \\
\text { penggunaan obat }\end{array}$ & 305 & 351 & 0.86 & 86.89 \\
\hline $\begin{array}{l}\text { Kewajaran biaya } \\
\text { pengobatan }\end{array}$ & 293 & 353 & 0.83 & 83 \\
\hline
\end{tabular}

\begin{tabular}{|c|c|c|c|c|}
\hline \multirow{2}{*}{ Pertanyaan } & \multicolumn{3}{|c|}{ Tanggapan Responden } & \multirow{2}{*}{$\begin{array}{l}\text { \%Skor } \\
\text { Aktual }\end{array}$} \\
\hline & Aktual & Ideal & $\mathbf{A} / \mathbf{I}$ & \\
\hline $\begin{array}{l}\text { Kenyamanan ruang } \\
\text { tunggu }\end{array}$ & 277 & 347 & 0.79 & 79.82 \\
\hline $\begin{array}{l}\text { Kenyamanan ruang } \\
\text { pemeriksaan }\end{array}$ & 279 & 347 & 0.80 & 80.40 \\
\hline $\begin{array}{l}\text { Kenyamanan ruang } \\
\text { tunggu pengambilan } \\
\text { obat }\end{array}$ & 275 & 345 & 0.79 & 79.71 \\
\hline $\begin{array}{ll}\text { Petunjuk } & \text { arah } \\
\text { poliklinik } & \\
\end{array}$ & 292 & 345 & 0.84 & 84.63 \\
\hline Kebersihan poliklinik & 283 & 353 & 0.80 & 80.16 \\
\hline Area parker & 244 & 342 & 0.71 & 71.34 \\
\hline Rata-Rata & 284.86 & 343.06 & 0.82 & 82.90 \\
\hline
\end{tabular}

Sumber: Rekapitulasi Kuesioner Penelitian Puskesmas Putri Ayu

Tabel 12.

Tingkat Kepuasan Pasien Terhadap Pelayanan Puskesmas Puskesmas Pakuan Baru

\begin{tabular}{|l|c|c|c|c|}
\hline \multirow{2}{*}{ Pertanyaan } & \multicolumn{2}{|c|}{ Tanggapan Responden } & \%Skor \\
\cline { 2 - 4 } & Aktual & Ideal & A/I & \\
\hline $\begin{array}{l}\text { Prosedur } \\
\text { pendaftaran } \\
\text { pasien }\end{array}$ & 305 & 326 & 0.93 & 93.55 \\
\hline $\begin{array}{l}\text { Prosedur } \\
\text { pemerikasaan \& } \\
\text { pengobatan }\end{array}$ & 304 & 313 & 0.97 & 97.12 \\
\hline $\begin{array}{l}\text { Prosedur } \\
\text { Pembayaran }\end{array}$ & 301 & 312 & 0.96 & 96.47 \\
\hline $\begin{array}{l}\text { Prosedur } \\
\text { pengambilan obat }\end{array}$ & 302 & 307 & 0.98 & 98.37 \\
\hline $\begin{array}{l}\text { Kejelasan waktu } \\
\text { tunggu } \\
\text { pemeriksaan }\end{array}$ & 300 & 350 & 0.85 & 82.85 \\
\hline $\begin{array}{l}\text { Kejelasan } \\
\text { informasi } \\
\text { penyakit }\end{array}$ & 308 & 354 & 0.87 & 87 \\
\hline $\begin{array}{l}\text { Kejelasan waktu } \\
\text { tunggu } \\
\text { pengambilan obat }\end{array}$ & 276 & 348 & 0.79 & 79.31 \\
\hline $\begin{array}{l}\text { Kejelasan } \\
\text { penggunaan obat }\end{array}$ & 305 & 351 & 0.86 & 86.89 \\
\hline $\begin{array}{l}\text { Kewajaran biaya } \\
\text { pengobatan }\end{array}$ & 293 & 353 & 0.83 & 83 \\
\hline $\begin{array}{l}\text { Kenyamanan } \\
\text { ruang tunggu }\end{array}$ & 289 & 354 & 0.81 & 81.63 \\
\hline $\begin{array}{l}\text { Kenyamanan } \\
\text { ruang ang } \\
\text { pemeriksaan }\end{array}$ & 288 & 352 & 0.81 & 81.81 \\
\hline $\begin{array}{l}\text { Kenyamanan } \\
\text { ruang } \\
\text { pengambilan obat }\end{array}$ & 302 & 354 & 0.85 & 85.31 \\
\hline $\begin{array}{l}\text { Petunjuk arah } \\
\text { poliklinik }\end{array}$ & & 354 & 0.85 & 85.31 \\
\hline $\begin{array}{l}\text { Kebersihan } \\
\text { poliklinik }\end{array}$ & & & & \\
\hline
\end{tabular}




\begin{tabular}{|c|c|c|c|c|}
\hline \multirow{2}{*}{ Pertanyaan } & \multicolumn{3}{|c|}{ Tanggapan Responden } & \%Skor \\
\cline { 2 - 4 } & Aktual & Ideal & A/I & \\
\hline Area parker & 256 & 354 & 0.72 & 72.31 \\
\hline Rata-Rata & $\mathbf{2 9 4 . 4 6}$ & $\mathbf{3 4 2 . 3 3}$ & $\mathbf{0 . 8 5}$ & $\mathbf{8 6 . 1 2}$ \\
\hline
\end{tabular}

Sumber: Rekapitulasi Kuesioner Penelitian Puskesmas Pakuan Baru

Dapat disimpulkan dilihat dari tingkat kepuasan pasien terhadap pelayanan karyawan antara Puskesmas Putri ayu dengan Puskesmas Pakuan baru sama-sama dalam kategori sangat baik, tetapi tingakat kepuasan pasien Puskesmas Pakuan Baru lebih baik walaupun tidak berbeda jauh yaitu persentase Puskesmas Putri ayu sebesar 82,90\% sedangkan Puskesmas Pakuan Baru $86,12 \%$.

Tabel 13.

Pertumbuhan Kunjungan Pelanggan Tahun 2015-2017 Puskesmas Putri Ayu

\begin{tabular}{|c|c|c|c|}
\hline Tahun & $\begin{array}{c}\text { Jumlah } \\
\text { Pelanggan }\end{array}$ & $\begin{array}{c}\text { Selisih } \\
\text { Jumlah } \\
\text { Pelanggan }\end{array}$ & $\begin{array}{c}\text { Tingkat } \\
\text { Pertumbuhan } \\
\text { Pelanggan }\end{array}$ \\
\hline 2015 & 51.381 & - & - \\
\hline 2016 & 63.836 & 12.455 & $24.24 \%$ \\
\hline 2017 & 74.647 & 10.811 & $16.94 \%$ \\
\hline $\begin{array}{c}\text { Rata- } \\
\text { rata }\end{array}$ & $\mathbf{6 3 . 2 8 8}$ & $\mathbf{7 . 7 5 5 , 3}$ & $\mathbf{2 5 . 0 2 \%}$ \\
\hline
\end{tabular}

Sumber: Rekam Medik Puskesmas Putri Ayu

Tabel 14.

Pertumbuhan Kunjungan Pelanggan Tahun 2015-2017 Puskesmas Pakuan Baru

\begin{tabular}{|c|c|c|c|}
\hline Tahun & $\begin{array}{c}\text { Jumlah } \\
\text { Pelanggan }\end{array}$ & $\begin{array}{c}\text { Selisih } \\
\text { Jumlah } \\
\text { Pelanggan }\end{array}$ & $\begin{array}{c}\text { Tingkat } \\
\text { Pertumbuhan } \\
\text { Pelanggan }\end{array}$ \\
\hline 2015 & 41.744 & - & - \\
\hline 2016 & 47.924 & 6.180 & $14.80 \%$ \\
\hline 2017 & 59.300 & 11.376 & $23.73 \%$ \\
\hline $\begin{array}{c}\text { Rata- } \\
\text { rata }\end{array}$ & $\mathbf{4 9 . 6 5 6}$ & $\mathbf{5 . 8 5 2}$ & $\mathbf{1 2 . 8 4 \%}$ \\
\hline
\end{tabular}

Sumber: Rekam Medik Puskesmas Pakuan Baru

Dapat disimpulkan dilihat dari pertumbuhan kunjungan pelanggan dari tahun 2015 sampai 2017, tingkat pertumbuhan kunjungan pelanggan Puskesmas Putri Ayu lebih baik dibandingkan dengan tingkat pertumbuhan Puskesmas Pakuan Baru dengan selisih sebesar $12,18 \%$.
Tabel 15.

Hasil Proses Inovasi

Puskesmas Putri Ayu

\begin{tabular}{|l|c|c|c|c|}
\hline \multirow{2}{*}{ Pertanyaan } & \multicolumn{2}{|c|}{ Tanggapan Responden } & \multirow{2}{*}{ \% Skor } \\
\cline { 2 - 4 } & Akrual & Ideal & A/I & \\
\hline $\begin{array}{l}\text { Apakah ada peningkatan } \\
\text { fasilitas rumah sakit } \\
\text { dalam proses } \\
\text { penyembuhan pasien? }\end{array}$ & 67 & 93 & 0.72 & 72.04 \\
\hline $\begin{array}{l}\text { Apakah ruang pasien } \\
\text { dibuat senyaman } \\
\text { mungkin? }\end{array}$ & 74 & 93 & 0.80 & 79.57 \\
\hline $\begin{array}{l}\text { Apakah ruang tunggu } \\
\text { dibuat senyaman } \\
\text { mungkin? }\end{array}$ & 76 & 93 & 0.82 & 81.72 \\
\hline $\begin{array}{l}\text { Apakah ada peningkatan } \\
\text { fasilitas dan pelayanan } \\
\text { seperti tempat beribadah } \\
\text { dan parker yang } \\
\text { memadai? }\end{array}$ & 52 & 92 & 0.56 & 56.52 \\
\hline Rata-rata & $\mathbf{6 7 . 2 5}$ & $\mathbf{9 2 . 7 5}$ & $\mathbf{0 . 7 2}$ & $\mathbf{7 2 . 4 6}$ \\
\hline
\end{tabular}

Sumber: Rekapitulasi Kuesioner Penelitian Puskesmas Putri Ayu

Tabel 16.

Hasil Proses Inovasi

Puskesmas Pakuan Baru

\begin{tabular}{|l|c|c|c|c|}
\hline \multirow{2}{*}{ Pertanyaan } & \multicolumn{2}{|c|}{ Tanggapan Responden } & \% Skor \\
\cline { 2 - 4 } & Akrual & Ideal & A/I & Akrual \\
\hline $\begin{array}{l}\text { Apakah ada peningkatan } \\
\text { fasilitas rumah sakit } \\
\text { dalam proses } \\
\text { penyembuhan pasien? }\end{array}$ & 64 & 93 & 0.68 & 68.81 \\
\hline $\begin{array}{l}\text { Apakah ruang pasien } \\
\text { dibuat senyaman } \\
\text { mungkin? }\end{array}$ & 72 & 93 & 0.77 & 77.41 \\
\hline $\begin{array}{l}\text { Apakah ruang tunggu } \\
\text { dibuat senyaman } \\
\text { mungkin? }\end{array}$ & 77 & 93 & 0.82 & 82.79 \\
\hline $\begin{array}{l}\text { Apakah ada peningkatan } \\
\text { fasilitas dan pelayanan } \\
\text { seperti laundry, tempat } \\
\text { beribadah dan parker } \\
\text { yang memadai? }\end{array}$ & 55 & 92 & 0.6 & 59.78 \\
\hline Rata-rata & $\mathbf{6 7}$ & $\mathbf{9 2 . 7 5}$ & $\mathbf{0 . 7 1}$ & $\mathbf{7 2 . 1 9}$ \\
\hline
\end{tabular}

Sumber: Rekapitulasi Kuesioner Penelitian Puskesmas Pakuan Baru

Dapat disimpulkan persentase Puskesmas Putri Ayu sebesar 72,46\% sedangkan Puskesmas Pakuan Baru dengan persentase sebesar 72,19\%. Puskesmas Putri Ayu sedikit lebih baik dengan selisih persentase sebesar $0,27 \%$. 
Tabel 17.

Hasil Proses Sistem dan Prosedur Puskesmas Putri ayu

\begin{tabular}{|c|c|c|c|c|}
\hline \multirow{2}{*}{ Pertanyaan } & \multicolumn{3}{|c|}{ Tanggapan Responden } & \multirow{2}{*}{$\begin{array}{l}\text { \% Skor } \\
\text { Akrual }\end{array}$} \\
\hline & Akrual & Ideal & $\mathbf{A} / \mathbf{I}$ & \\
\hline $\begin{array}{l}\text { Apakah ada pembuatan } \\
\text { Protap dan SOP di } \\
\text { Puskesmas Putri Ayu? }\end{array}$ & 59 & 83 & 0.71 & 71.08 \\
\hline 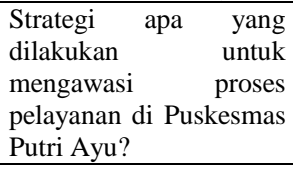 & 64 & 85 & 0.75 & 75.29 \\
\hline Rata-rata & 61.5 & 84 & $\mathbf{0 . 7 3}$ & 73.19 \\
\hline
\end{tabular}

Sumber: Rekapitulasi Kuesioner Penelitian Puskesmas Putri Ayu

Tabel 18.

Hasil Proses Sistem dan Prosedur

\begin{tabular}{|c|c|c|c|c|}
\hline \multirow{2}{*}{$\begin{array}{c}\text { Puskesmas Pakuan } \\
\text { BaruPertanyaan }\end{array}$} & \multicolumn{3}{|c|}{ Tanggapan Responden } & \multirow{2}{*}{$\begin{array}{l}\text { \% Skor } \\
\text { Akrual }\end{array}$} \\
\hline & Akrual & Ideal & $\mathbf{A} / \mathbf{I}$ & \\
\hline $\begin{array}{l}\text { Apakah ada pembuatan } \\
\text { Protap dan SOP di } \\
\text { Puskesmas Putri Ayu? }\end{array}$ & 57 & 83 & 0.68 & 68.67 \\
\hline $\begin{array}{lrr}\text { Strategi } & \text { apa } & \text { yang } \\
\text { dilakukan } & \text { untuk } \\
\text { mengawasi } & \text { proses } \\
\text { pelayanan di Puskesmas } \\
\text { Putri Ayu? }\end{array}$ & 63 & 85 & 0.74 & 74.11 \\
\hline Rata-rata & 60 & 84 & 0.71 & 71.39 \\
\hline
\end{tabular}

Sumber: Rekapitulasi Kuesioner Penelitian Puskesmas Putri Ayu

Dapat disimpulkan dilihat dari proses sistem dan prosedur Puskesmas ternyata kedua puskesmas ini sama-sama masuk kedalam kategori baik dengan persentase masing-masing, Puskesmas Putri Ayu dengan persentase sebesar $73,19 \%$ sedangkan Puskesmas Pakuan Baru dengan persentase sebesar 71,39\% ini berarti Puskesmas Putri Ayu sedikit lebih baik bila dilihat dari proses dan prosedur puskesmas dengan selisih sebesar $1,8 \%$.

Tabel 19.

Kelengkapan Fasilitas

Puskesmas Putri Ayu

\begin{tabular}{|c|c|c|c|c|}
\hline \multirow{2}{*}{ Pertanyaan } & \multicolumn{3}{|c|}{ Tanggapan Responden } & \multirow{2}{*}{$\begin{array}{l}\text { \% Skor } \\
\text { Akrual }\end{array}$} \\
\hline & Akrual & Ideal & $\mathbf{A} / \mathbf{I}$ & \\
\hline $\begin{array}{lr}\begin{array}{l}\text { Menurut } \\
\text { bagaimana }\end{array} & \text { Saudara } \\
\text { kelengkenai } \\
\text { Puskesmas? } & \text { fasilitas } \\
\end{array}$ & 61 & 97 & 0.62 & 62.88 \\
\hline 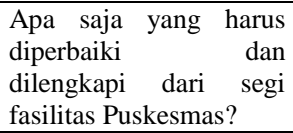 & 57 & 96 & 0.59 & 50.37 \\
\hline Rata-rata & 59 & 96.5 & 0.47 & 56.62 \\
\hline
\end{tabular}

Sumber: Rekapitulasi Kuesioner Penelitian Puskesmas Putri Ayu
Tabel 20.

Kelengkapan Fasilitas

Puskesmas Putri Pakuan Baru

\begin{tabular}{|c|c|c|c|c|}
\hline \multirow{2}{*}{ Pertanyaan } & \multicolumn{3}{|c|}{$\begin{array}{l}\text { Tanggapan Responden } \\
\end{array}$} & \multirow{2}{*}{$\begin{array}{l}\text { \% Skor } \\
\text { Akrual }\end{array}$} \\
\hline & Akrual & Ideal & $\mathbf{A} / \mathbf{I}$ & \\
\hline $\begin{array}{lr}\begin{array}{l}\text { Menurut } \\
\text { bagaimana }\end{array} & \text { Saudara } \\
\text { kelengenaipan } \\
\text { Puskesmas? } & \text { fasilitas } \\
\end{array}$ & 48 & 96 & 0.49 & 49.48 \\
\hline \begin{tabular}{lrr} 
Apa saja yang & harus \\
diperbaiki & & dan \\
dilengkapi dari & segi \\
\multicolumn{2}{l}{ fasilitas Puskesmas? }
\end{tabular} & 46 & 96 & 0.47 & 47.91 \\
\hline Rata-rata & 47 & 96 & 0.48 & 48.69 \\
\hline
\end{tabular}

Sumber: Rekapitulasi Kuesioner Penelitian Puskesmas

\section{Pakuan Baru}

Dapat disimpulkan dilihat dari kelengkapan fasilitas puskesmas kedua puskesmas ini hanya masuk kedalam kategori cukup baik, Puskesmas Putri Ayu dengan persentase sebesar 56,62\% sedangkan Puskesmas Pakuan Baru dengan persentase sebesar 48,69\% ini berarti Puskesmas Putri Ayu sedikit lebih baik bila dilihat dari kelengkapan Fasilitas dengan selisih $7,93 \%$.

Tabel 21.

Kapabilitas Karyawan

Puskesmas Putri Ayu

\begin{tabular}{|l|c|c|c|c|}
\hline \multicolumn{2}{|c|}{ Pertanyaan } & \multicolumn{2}{|c|}{ Tanggapan Responden } & \% Skor \\
\cline { 2 - 4 } & Akrual & Ideal & A/I & \\
\hline $\begin{array}{l}\text { Bapak/Ibu puas dengan } \\
\text { standar honor/gaji yang } \\
\text { telah di tetapkan saat ini }\end{array}$ & 65 & 88 & 0.73 & 73.86 \\
\hline $\begin{array}{l}\text { Gaji yang diberikan } \\
\text { sesuai dengan peran dan } \\
\text { tanggung jawab yang } \\
\text { diberikan }\end{array}$ & 63 & 88 & 0.71 & 71.59 \\
\hline $\begin{array}{l}\text { Ditempat Bapak/Ibu } \\
\text { bekerja kenaikan gaji } \\
\text { terjadi secara berkala. }\end{array}$ & 66 & 91 & 0.72 & 72.52 \\
\hline $\begin{array}{l}\text { Tunjangan yang } \\
\text { diterima sudah } \\
\text { memuaskan Bapak/Ibu }\end{array}$ & 65 & 90 & 0.72 & 72.22 \\
\hline $\begin{array}{l}\text { Tunjang yang Bapak/Ibu } \\
\text { terima dibayarkan tepat } \\
\text { waktu }\end{array}$ & 69 & 90 & 0,76 & 76.66 \\
\hline $\begin{array}{l}\text { Bapak/Ibu puas dengan } \\
\text { kemajuan karir } \\
\text { Bapak/Ibu saat ini }\end{array}$ & 64 & 91 & 0.65 & 64.84 \\
\hline $\begin{array}{l}\text { Posisi yang Bapak/Ibu } \\
\text { tempati sudah sesuai } \\
\text { dengan keinginan } \\
\text { Bapak/Ibu }\end{array}$ & 69 & 91 & 0.70 & 70.32 \\
\hline $\begin{array}{l}\text { Bapak/Ibu menyukai } \\
\text { cara Puskesmas/Atasan } \\
\text { melakukan promosi } \\
\text { terhadap pegawai }\end{array}$ & 76 & 91 & 0.83 & 83.51 \\
\hline $\begin{array}{l}\text { Puaskah Bapak/Ibu } \\
\text { terhadap gaya } \\
\text { kepemimpinan atasan } \\
\text { yang sekarang }\end{array}$ & 74 & 89 & 0.83 & 83.14 \\
\hline $\begin{array}{l}\text { Atasan } \\
\text { memberikan pujian atas }\end{array}$ & 75 & 88 & 0.85 & 85.22 \\
\hline
\end{tabular}




\begin{tabular}{|l|c|c|c|c|}
\hline $\begin{array}{l}\text { prestasi yang saya } \\
\text { lakukan. }\end{array}$ & & & & \\
\hline Rata-rata & $\mathbf{6 8 . 6}$ & $\mathbf{8 9 , 7}$ & $\mathbf{0 . 7 5}$ & $\mathbf{7 5 . 3 8}$ \\
\hline
\end{tabular}

Sumber: Rekapitulasi Kuesioner Penelitian Puskesmas Putri Ayu

Tabel 22.

Kapabilitas Karyawan

Puskesmas Pakuan Baru

\begin{tabular}{|c|c|c|c|c|}
\hline \multirow{2}{*}{ Pertanyaan } & \multicolumn{3}{|c|}{ Tanggapan Responden } & \multirow{2}{*}{$\begin{array}{l}\text { \% Skor } \\
\text { Akrual }\end{array}$} \\
\hline & Akrual & Ideal & $\mathbf{A} / \mathbf{I}$ & \\
\hline $\begin{array}{l}\text { Bapak/Ibu puas dengan } \\
\text { standar honor/gaji yang } \\
\text { telah di tetapkan saat ini }\end{array}$ & 58 & 90 & 0.64 & 64.44 \\
\hline $\begin{array}{l}\text { Gaji yang diberikan } \\
\text { sesuai dengan peran dan } \\
\text { tanggung jawab yang } \\
\text { diberikan }\end{array}$ & 58 & 90 & 0.64 & 64.44 \\
\hline $\begin{array}{l}\text { Ditempat Bapak/Ibu } \\
\text { bekerja kenaikan gaji } \\
\text { terjadi secara berkala }\end{array}$ & 62 & 93 & 0.66 & 66.66 \\
\hline $\begin{array}{lr}\text { Tunjangan } & \text { yang } \\
\text { diterima } & \text { sudah } \\
\text { memuaskan Bapak/Ibu }\end{array}$ & 58 & 91 & 0.63 & 63.73 \\
\hline $\begin{array}{l}\text { Tunjang yang Bapak/Ibu } \\
\text { terima dibayarkan tepat } \\
\text { waktu }\end{array}$ & 60 & 90 & 0,66 & 66.66 \\
\hline $\begin{array}{l}\text { Bapak/Ibu puas dengan } \\
\text { kemajuan } \\
\text { Bapak/Ibu saat ini }\end{array}$ & 62 & 93 & 0.66 & 66.66 \\
\hline $\begin{array}{lrr}\text { Posisi } & \text { yang } & \text { Bapak/Ibu } \\
\text { tempati } & \text { sudah } & \text { sesuai } \\
\text { dengan } & \text { keinginan } \\
\text { Bapak/Ibu } & \\
\end{array}$ & 68 & 91 & 0.74 & 74.72 \\
\hline $\begin{array}{l}\text { Bapak/Ibu menyukai } \\
\text { cara Puskesmas/Atasan } \\
\text { melakukan promosi } \\
\text { terhadap pegawai }\end{array}$ & 67 & 91 & 0.73 & 73.63 \\
\hline $\begin{array}{lr}\text { Puaskah } & \text { Bapak/Ibu } \\
\text { terhadap } & \text { gaya } \\
\text { kepemimpinan } & \text { atasan } \\
\text { yang sekarang } & \\
\end{array}$ & 60 & 89 & 0.67 & 67.41 \\
\hline $\begin{array}{lr}\text { Atasan } & \text { saya } \\
\text { memberikan pujian atas } \\
\text { prestasi yang saya } \\
\text { lakukan. }\end{array}$ & 63 & 88 & 0.71 & 71.59 \\
\hline Rata-rata & 61.6 & 90.6 & 0.60 & 67.99 \\
\hline
\end{tabular}

Sumber: Rekapitulasi Kuesioner Penelitian Puskesmas Pakuan Baru

Dapat disimpulkan dilihat dari tingkat kapasitas karyawan Puskesmas Putri Ayu lebih baik dibandingkan dengan Puskesmas Pakuan Baru dengan Selisih 7,39\%, Puskesmas Ayu dengan Persentase sebesar 75,38\% sedangkan Puskesmas Pakuan Baru dengan Persentase sebesar $67,99 \%$ tetapi kedua puskesmas ini masih masuk kedalam kategori baik apabila dilihat dari tingkat kapasitas karyawan puskesmas.
Tabel 23.

Kapabilitas Sistem Informasi

Puskesmas Putri Ayu

\begin{tabular}{|c|c|c|c|c|}
\hline \multirow{2}{*}{ Pertanyaan } & \multicolumn{3}{|c|}{ Tanggapan Responden } & \multirow{2}{*}{$\begin{array}{l}\text { \% Skor } \\
\text { Akrual }\end{array}$} \\
\hline & Akrual & Ideal & $\mathbf{A} / \mathbf{I}$ & \\
\hline 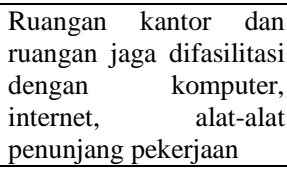 & 68 & 91 & 0,74 & 74.72 \\
\hline $\begin{array}{lr}\text { Teknologi } & \text { yang } \\
\text { digunakan } & \text { dapat } \\
\text { memberikan } & \text { informasi } \\
\text { yang jelas. } & \\
\end{array}$ & 67 & 89 & 0,75 & 75.26 \\
\hline $\begin{array}{ll}\begin{array}{l}\text { Pembinaan } \\
\text { pengguna }\end{array} & \text { dalam } \\
\text { informasi } & \text { sistem } \\
\end{array}$ & 63 & 88 & 0,71 & 71.59 \\
\hline Rata-rata & 66 & 89,33 & $\mathbf{0 , 7 3}$ & 73,68 \\
\hline
\end{tabular}

Sumber: Rekapitulasi Kuesioner Penelitian Puskesmas Putri Ayu

Tabel 24.

Kapabilitas Sistem Informasi Puskesmas Pakuan Baru

\begin{tabular}{|l|c|c|c|c|}
\hline \multirow{2}{*}{ Pertanyaan } & \multicolumn{3}{|c|}{ Tanggapan Responden } & \% Skor \\
\cline { 2 - 4 } & Akrual & Ideal & A/I & Akrual \\
\hline $\begin{array}{l}\text { Ruangan kantor dan } \\
\text { ruangan jaga difasilitasi } \\
\text { dengan komputer, } \\
\text { internet, } \begin{array}{r}\text { alat-alat } \\
\text { penunjang pekerjaan }\end{array}\end{array}$ & 65 & 90 & 0,72 & 72.22 \\
\hline $\begin{array}{l}\text { Teknologi yang } \\
\text { digunakan dapat } \\
\text { memberikan informasi } \\
\text { yang jelas. }\end{array}$ & 63 & 90 & 0,70 & 70 \\
\hline $\begin{array}{l}\text { Pembinaan dalam } \\
\text { pengguna } \\
\text { informasi }\end{array}$ & 56 & 88 & 0,63 & 63,63 \\
\hline Rata-rata & $\mathbf{6 1 , 3 3}$ & $\mathbf{8 9 , 3 3}$ & $\mathbf{0 , 6 8}$ & $\mathbf{6 8 , 6 1}$ \\
\hline
\end{tabular}

Dapat disimpulkan dilihat dari kapasitas sistem informasi Puskesmas, kedua puskesmas ini masuk kedalam kategori baik, dengan masing-masing persentase Puskesmas Putri Ayu sebesar 73,68\% sedangkan Puskesmas Pakuan Baru dengan persentase sebesar 68,61\% ini berarti Puskesmas Putri Ayu lebih Baik dibandingkan dengan Puskesmas Pakuan Baru dilihat kapasitas sistem informasi dengan selisih 5,07\%.

Tabel 25.

Hasil Uji Normalitas Data (Kenyataan)

\begin{tabular}{|l|c|c|}
\hline \multicolumn{1}{|c|}{ Perspektif } & $\begin{array}{c}\text { Kolmogorov - } \\
\text { Smirnov } \\
\mathbf{Z}\end{array}$ & Signifikansi \\
\hline Pelanggan & 0,789 & 0,000 \\
\hline $\begin{array}{l}\text { Pembelajaran dan } \\
\text { Pertumbuhan }\end{array}$ & 0,905 & 0,000 \\
\hline Bisnis Internal & 0,566 & 0,000 \\
\hline
\end{tabular}

Dari Tabel 4.25 tersebut berdasarkan sigi kenyataan, nilai signifikansi ketiga variabel adalah 
$0,000<$ alpha $(\alpha=0,05)$. Jadi dapat disimpulkan bahwa ketiga variabel perspektif balanced scorecard tersebut akan diuji dengan metode statistik non parametrik karena berdistribusi normal.

Tabel 26.

Hasil Uji Normalitas Data (Harapan)

\begin{tabular}{|l|c|c|}
\hline \multicolumn{1}{|c|}{ Perspektif } & $\begin{array}{c}\text { Kolmogorov - } \\
\text { Smirnov } \\
\mathbf{Z}\end{array}$ & Signifikansi \\
\hline Pelanggan & 0,421 & 0,000 \\
\hline $\begin{array}{l}\text { Pembelajaran dan } \\
\text { Pertumbuhan }\end{array}$ & 0,871 & 0,000 \\
\hline Bisnis Internal & 0,855 & 0,000 \\
\hline
\end{tabular}

Data perspektif keuangan berbentuk rasio sehingga perspektif keuangan diuji dengan uji statistik parametrik uji beda $\mathrm{t}$ berpasangan (paired sample $t$ test). Nilai probabilitas perspektif keuangan dari segi rasio pendapatan menunjukkan angka $0,128>$ alpha $(\alpha$ : $2=0,025$ ). Jadi bisa disimpulkan bahwa tidak ada perbedaan signifikan antara rasio perspektif pendapatan Puskesmas Putri dan Puskesmas Pakuan Baru yang mana t hitung sebesar 2,522 berarti rata-rata rasio perspektif pendapatan Puskesmas Putri lebih tinggi dari pada rasio perspektif pendapatan Puskesmas Pakuan Baru.

Nilai probabilitas perspektif keuangan dari segi rasio pengeluaran menunjukkan angka 0,062 > alpha $(\alpha: 2=0,025)$. Jadi bisa disimpulkan bahwa tidak ada perbedaan signifikan antara rasio perspektif pengeluaran Puskesmas Putri dan Puskesmas Pakuan Baru yang mana t hitung sebesar 3,661 berarti rata-rata rasio perspektif pengeluaran Puskesmas Putri lebih rendah dari pada rasio perspektif pengeluaran Puskesmas Pakuan Baru.

Nilai probabilitas perspektif keuangan dari segi rasio CCR menunjukkan angka 0,671 > alpha $(\alpha: 2=$ 0,025). Jadi bisa disimpulkan bahwa tidak ada perbedaan signifikan antara rasio perspektif CCR Puskesmas Putri dan Puskesmas Pakuan Baru yang mana nilai Mean: 4,47667. Bernilai Positif: Artinya terjadi kecenderungan penurunan rasio CCR Puskesmas Pakuan Baru dibandingkan rasio CCR Puskesmas Putri dengan rata-rata penurunannya adalah 4,47667. Atau dilihat t-hitung sebesar 0,493 berarti rata-rata rasio perspektif CCR Puskesmas Putri lebih tinggi dari pada rasio perspektif CCR Puskesmas Pakuan Baru.
Tabel 27.

Hasil Uji Statistik Parametrik dan Non Parametrik

\begin{tabular}{|c|c|c|c|}
\hline \multirow{4}{*}{$\begin{array}{l}\text { Uji Non- } \\
\text { Parametrik }\end{array}$} & Perspektif & $\begin{array}{c}\text { Nilai } \\
\text { Asymp. Sig. } \\
\text { (2- tailed) }\end{array}$ & Mean \\
\hline & $\begin{array}{l}\text { Pelangga } \\
\text { n } \\
\text { Puskesmas Putri } \\
\text { Puskesmas } \\
\text { Pakuan Baru }\end{array}$ & 0,000 & $\begin{array}{l}288,60 \\
302,72\end{array}$ \\
\hline & $\begin{array}{l}\text { Pembelajaran dan } \\
\text { Pertumbuhan } \\
\text { Puskesmas Putri } \\
\text { Puskesmas } \\
\text { Pakuan Baru } \\
\end{array}$ & 0,001 & $\begin{array}{l}68,00 \\
61,54\end{array}$ \\
\hline & $\begin{array}{l}\text { Bisnis Internal } \\
\text { Puskesmas Putri } \\
\text { Puskesmas } \\
\text { Pakuan Baru }\end{array}$ & 0,122 & $\begin{array}{l}63,75 \\
60,25\end{array}$ \\
\hline \multirow{3}{*}{$\begin{array}{c}\text { Uji } \\
\text { Parametrik }\end{array}$} & $\begin{array}{l}\text { Pendapatan } \\
\text { Puskesmas Putri } \\
\text { Puskesmas Pakuan } \\
\text { Baru }\end{array}$ & 0,128 & $\begin{array}{c}48,54 \\
7,70\end{array}$ \\
\hline & $\begin{array}{l}\text { Pengeluaran } \\
\text { Puskesmas Putri } \\
\text { Puskesmas } \\
\text { Pakuan Baru }\end{array}$ & 0,067 & $\begin{array}{l}13,37 \\
14,95\end{array}$ \\
\hline & $\begin{array}{l}\text { CCR } \\
\text { Puskesmas Putri } \\
\text { Puskesmas } \\
\text { Pakuan Baru }\end{array}$ & 0,671 & $\begin{array}{l}120,74 \\
116,27\end{array}$ \\
\hline
\end{tabular}

Uji non parametrik yang digunakan dalam penelitian ini adalah uji Willcoxon dan uji MannWhitney $U$. Pada perspektif pelanggan, nilai Asymp. Sig. (2-tailed) sebesar $0,000<$ alpha $(\alpha: 2=$ 0,025 ), dengan $\mathrm{p}$ value (Asymp. Sig 2 tailed) sebesar 0,000 di mana kurang dari batas kritis penelitian 0,05 sehingga keputusan hipotesis adalah menerima $\mathrm{H} 1$ atau yang berarti terdapat perbedaan. Sehingga dapat disimpulkan bahwa secara statistik terdapat perbedaan antara rata-rata perspektif kepuasan pelanggan Puskesmas Putri dan Puskesmas Pakuan Baru.

Pada perspektif proses pembelajaran dan pertumbuhan, nilai Asymp. Sig. (2-tailed) sebesar $0,001<$ alpha $(\alpha: 2=0,025)$, dengan $\mathrm{p}$ value (Asymp. Sig 2 tailed) sebesar 0,001 di mana kurang dari batas kritis penelitian 0,05 sehingga keputusan hipotesis adalah menerima $\mathrm{H} 1$ atau yang berarti terdapat perbedaan. Sehingga dapat disimpulkan bahwa secara statistik terdapat perbedaan antara rata-rata perspektif pembelajaran dan pertumbuhan Puskesmas Putri dan Puskesmas Pakuan Baru.

Pada perspetif bisnis internal, nilai Asymp. Sig. (2-tailed) sebesar $0,122>$ alpha $(\alpha: 2=0,025)$, sehingga dapat disimpulkan bahwa tidak terdapat perbedaan yang signifikan antara rata-rata perspektif bisnis internal Puskesmas Putri dan Puskesmas Pakuan Baru. Hal ini dikarenakan diatas dari batas kritis penelitian 0,05 sehingga keputusan hipotesis adalah menolak $\mathrm{H} 1$ atau yang berarti secara statistik tidak 
terdapat perbedaan yang signifikan antara rata-rata perspektif bisnis internal Puskesmas Putri dan Puskesmas Pakuan Baru.

\section{SIMPULAN DAN SARAN}

\subsection{Simpulan}

Berdasarkan hasil pengujian, dapat dapat disimpulkan bahwa Pengukuran kinerja Puskesmas Putri Ayu dan Puskesmas Pakuan baru dengan menggunakan metode balanced scorecard di lihat dari empat perspektif yaitu perspektif keuangan, perspektif kepuasan pelanggan, proses bisnis dan internal dan perspektif pembelajaran dan pertumbuhan, ternyata dari hasi pengujian perspektif keuangan dan perspektif bisnis internal tidak terdapat perbedaan yang signifikan, sedangakan perspektif proses pembelajaran dan pertumbuhan, proses kepusan pelanggan terdapat perbedaan.

\subsection{Saran}

Puskesmas harus mengevaluasi kinerja keuangan terutama dipenggunaan anggaran atau pengeluaran puskesmas juga pertumbuhan dan pembelajaran perlu dilakukan evaluasi dalam penetapan pemberian jasa, insentif, sistem penghargaan agar adanya motivasi bagi karyawan untuk bekerja lebih baik lagi.

\section{DAFTAR REFERENSI}

Ardianto, E. 2010. Metodologi Penelitian untuk Public Relations Kuantitatif dan Kualitatif Bandung: Simbiosa Rekatama Media.

Ciptani, Monika K. 2000. Jurnal Akutansi dan Keuangan Vol 2. Balanced scorecard Sebagai Pengukur Kinerja Masa depan: Suatu Pengantar: Universitas Kristen Petra.

Cooper,Donald. 2006. Metode Riset Bisnis. Edisi 9. Jakarta: PT Media Global Edukasi

Dahniar, Siti. 2015. Kinerja Puskesmas Tanjung Selor Kabupaten Bulungan Menggunakan Pendekatan Balanced Scorecard. Tesis. Jakarta: Universitas Terbuka

Departemen Kesehatan RI. 2016. Standar Pelayanan Minimal Rumah Sakit. Jakarta: Dirjen Binkesmas.

Gaspersz, V. 2005. Sistem Manajemen Kinerja Terintegrasi Balanced Scorecard Dengan Six Sigma Untuk Organisasi Bisnis dan Pemerintah. Edisi 3. Jakarta: PT. Gramedia Pustaka Utama.
Gaspersz, V. 2014. Sistem Manajemen Kinerja Terintegrasi Balanced Scorecard Dengan Six Sigma Untuk Organisasi Bisnis dan Pemerintah. Edisi 4. Jakarta: PT. Gramedia Pustaka Utama.

Gerson, R.F. 2004. Mengukur Kepuasan Pelanggan. Cetakan ke-3. Jakarta Pusat: Victory Jaya Abadi.

Gibson, James, L. 2000. Organisasi, Perilaku, Struktur dan Proses. Edisi ke-5. Cetakan ke-3. Jakarta: Penerbit Erlangga.

Ghozali, Imam. 2011. Aplikasi Analisis Multivariate dengan Program SPSS. Semarang: Badan Penerbit Universitas Diponegoro, Semarang.

Hafizurrachman, HM. 2009. Jurnal Manajemen Pendidikan dan Kesehatan: Penerapan Konse $p$ dan Variabel Kinerja, Gaya Kepemimpinan, Lingkungan, dan Motivasi Kerja. Jakarta: CV. Sagung Seto.

Hasan, I. 2006. Analisis Data Penelitian dengan Statistik. Jakarta: Bumi Aksara.

Herlambang, Susatyo. 2016, Manajemen Pelayanan Kesehatan Rumah Sakit, Cara Mudah Memahami Manajemen Pelayanan di Rumah Sakit dan Organisasi Pelayanan Kesehatan Lainnya, Yogyakarta: Gosyen Publishing.

Kaplan, R.S dan Norton, P.N. 2000. Menerapkan Strategi menjadi Aksi Balanced Scorecard. Jakarta: Erlangga.

Ilyas, Y. 2002. Kinerja: Teori, Perilaku dan Penelitian. Jakarta: Pusat Kajian Ekonomi.

Mardiasmo. 2002. Akuntansi Sektor Publik. Yogyakarta: Andi.

Mulyadi. 2001. Balanced scorecard Alat Manajemen Konteporer untuk Pelipat Ganda Kinerja Keuangan Perusahaan. Jakarta: Salemba Empat.

Mulyadi. 2007. Alat Manajemen Kontemporer untuk Pelipatganda Kinerja Keuangan Perusahaan Balanced Scorecard. Jakarta: Salemba Empat.

Munawir, S. 1989. Analisa Laporan Keuangan. Yogyakarta: Penerbit Liberty

Nasir, A., Muhith, A., dan Ideputri, E.M. 2011.Metodologi Penelitian Kesehatan Yogyakarta: Nuha Medika.

Natadipura, M. Iqbal. 200. Analisis Kinerja Puskesmas Emparu Kabupaten Sintang Berdasarkan Pendekatan Balanced Scorecard. Tesis. Jakarta: Universitas Terbuka. 
Nor, Liyana. 2010. Jurnal Kemanusiaan. Tenaga Kerja, Motivasi dan Kepusan Kerja Tentara Laut Armada Tentara Laut Diraja Malaysia. Malaysia.

Nuryaman, 2015. Metodologi Penelitian Akuntansi dan Bisnis Teori dan Praktik. Cetakan Pertama. Bogor: Ghalia Indonesia.

Panter, A.T., Swygert, K.A., Danistrom, W.G., Tanaka. 1997. Factor Analytic Approaches to Personality Item-Level Data. Journal of Personality Assement. Vol 68.

Rani, Novi \& Mildawati, Titik. 2014. Penerapan Strategi Balanced Scorecard Sebagai Alat Pengukur Kinerja Karyawan Puskesmas Bangkingan Surabaya. Jurnal Ilmu \& Riset Akuntansi Vol.3 No.9

Sabarguna, Boy S. 2007. Knowledge Management untuk Rumah Sakit. Jakarta: Sagung Seto.

Suhardi. 2009. Jurnal Tesis: Analisis Kesesuaian Antara Harapan dan Kenyataan Mutu Pelayanan Yang Diterima di Unit Rawat Inap RSUD Dr. Raden Soedjati Soemodiardjo Kabupaten Grobogan. Semarang: UNDIP.

Sugiyono. 2007.Metode Penelitian Bisnis. Bandung: ALFABETA

Sugiyono. 20011.Metode Penelitian Bisnis. Bandung: ALFABETA

Supranto, J. 2007. Pengukuran Tingkat Kepuasan Pelanggan. Jakarta: Penerbit PT Rineka Cipta.

Tjiptono, Fandy. 2004. Pemasaran Jasa. Jawa Timur: Bayumedia Publishing 